\title{
JUURNAL_RU
}

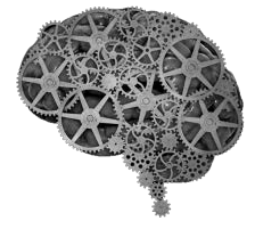

COMPANY GROUP "INTELLEKT"

Кобылкин С.Б. Ливенский филиал Орловский государственный университет им. И.С. Тургенева Ливны, Россия

doi: 10.18411/lj2016-6-1-12

\section{Прожиточный минимум в системе уровня жизни населения}

Анализ уровня жизни населения является злободневной темой, особенно учитывая настораживающую динамику его снижения в последние годы. Он рассчитываетсяна основании доходов на душу населения, реально имевших место, и объеме потребленных товаров и услуг.В соответствии с теориями рационального поведения наемных работников, основным показателем уровня жизни выступают их доходы[1]. В настоящее время номинальные доходы занятых в России растут наименьшими темпами - около 4-5\% в год, реальныедоходы падают рекордными темпами - около 9-11\% в год.При этом особое значение приобретает определение минимальных средств существования, где важным показателем при определении уровня жизни является прожиточный минимум. Проблемы, связанные с этим показателем остаются актуальными.

Целью работы является исследование роли прожиточного минимума в системе уровня жизни населения и анализ динамики.

Прожиточный минимум - социально-экономическая категория, характеризующая минимум жизненных средств, физически необходимый для поддержания жизнедеятельности работника и восстановления его рабочей силы[2].Величина прожиточного минимума в России регулируется соответствующим Федеральным законом, который регламентирует также и критерии, согласно которым определяется, каким конкретно должен быть 
прожиточный минимум на определенный отрезок времени, определяет методику расчета того, каким должен быть прожиточный минимум на человека.Размер прожиточного минимума определяется на уровне Правительства. Все необходимые данные предоставляет департамент доходов населения Министерства труда Российской Федерации.В региональном разрезе величина прожиточного минимума определяется законодателями регионального уровня для планирования экономики, учитывая особенности и состояние экономики региона, социальное положение населения, проживающего на территории конкретного субъекта Российской Федерации.

Принцип, по которому в различных регионах России определяется прожиточный минимум, не имеет единого алгоритма. Его величина определяется с разбивкой по категориям населения по следующим социальным признакам: трудоспособные граждане, пенсионеры, дети и средний показатель.

Величина прожиточного минимума в среднем на душу населения России представлена в таблице 1.

Таблииа 1

\begin{tabular}{|c|c|c|c|c|c|c|c|c|c|c|c|}
\hline Период & 2005 & 2006 & 2007 & 2008 & 2009 & 2010 & 2011 & 2012 & 2013 & 2014 & 2015 \\
\hline $\begin{array}{c}\text { Прожиточный } \\
\text { минимум на } \\
\text { душу } \\
\text { населения, руб. }\end{array}$ & 3018 & 3422 & 3847 & 4593 & 5153 & 5688 & 6369 & 6510 & 7306 & 8050 & 9701 \\
\hline $\begin{array}{c}\text { Относительноеи } \\
\text { зменение, \% }\end{array}$ & - & 113,4 & 112,4 & 119,4 & 112,2 & 110,4 & 112 & 102,2 & 112,2 & 110,2 & 120,5 \\
\hline
\end{tabular}

Наблюдается восходящая динамика изменения прожиточного минимума в среднем на душу населения с 3018 рублей в 2005 году до 9701 рублей в 2015 году[3].Повышение прожиточного минимума связано в основном с ростом цен. В России сложилась парадоксальная ситуация, когда официальный минимальный размер оплаты труда (МРОТ) ниже, чем физически необходимый для проживания (таблица2), хотя в Трудовом кодексе в статье 133 определено, что минимальныйразмероплатытруда не может быть ниже величины прожиточногоминимума трудоспособного населения[3]. 
Таблица2

Соотношение прожиточного минимума и минимального размера оплаты труда

\begin{tabular}{|c|c|c|c|c|c|c|c|c|c|c|c|c|}
\hline \multirow{2}{*}{$\begin{array}{c}\text { Показател } \\
\text { и }\end{array}$} & \multicolumn{2}{|c|}{ Годы } \\
\cline { 2 - 12 } & 2000 & 2005 & 2006 & 2007 & 2008 & 2009 & 2010 & 2011 & 2012 & 2013 & 2014 & 2015 \\
\hline $\begin{array}{c}\text { Прожиточ } \\
\text { ный } \\
\text { минимум } \\
\text { на душу } \\
\begin{array}{c}\text { населения, } \\
\text { руб. }\end{array}\end{array}$ & 1210 & 3018 & 3422 & 3847 & 4593 & 5153 & 5688 & 6369 & 6510 & 7306 & 8050 & 9701 \\
\hline $\begin{array}{c}\text { МРОТ, } \\
\text { руб. }\end{array}$ & 132 & 800 & 1100 & 1100 & 2300 & 2300 & 4330 & 4611 & 4611 & 5205 & 5554 & 5965 \\
\hline $\begin{array}{c}\text { Относител } \\
\text { ьное } \\
\text { изменение, } \\
\%\end{array}$ & 10,9 & 26,5 & 32,1 & 28,6 & 50,1 & 44,6 & 76,1 & 72,4 & 70,8 & 71,2 & 69 & 61,5 \\
\hline
\end{tabular}

В течение исследуемого периода 2000-2015 гг. наблюдается в целом положительная динамика увеличения удельного веса MPOT в величине прожиточного минимума на душу населения. Исключение составляют кризисные явления в экономике 2008-2009 гг. (падение с 50,1 \% до 44,6 \%), 2012 г. (незначительное снижение до 70,8 \%), а также 2014-2015 гг. (снижение, соответственно, до 69 \% и 61,5\%).

На начало 2016 года прожиточный минимум в расчете на одного человека равен 9452 руб., что на 221 руб. меньше, чем в предыдущем квартале. Прожиточный минимум для работающих граждан составляет 10187 руб., для людей пенсионного возраста - 7781 руб., для несовершеннолетних - 9197 руб. По сравнению с предыдущим кварталом, величина прожиточного минимума в России снижена более чем на 2\%[3]. Эта инициатива была реализована с подачи Министерства труда, которое заявило о снижении цен на потребительские продукты.

Парадоксальность принятых цифр специалисты объясняют несовершенством методики расчета стоимости минимальной потребительской корзины, на основании которой происходит определение прожиточного минимума. Стоимость фиксированного набора потребительских товаров и услуг на январь 2016 года составила 13517 рублей, что на 1011 рублей больше чем в 2015 году (12506 рублей). По данным статистики, свыше 19 миллионов граждан 
России имеют доходы ниже прожиточного минимума[3]. Несмотря на увеличение с 1 января 2016 года МРОТ до 6204 руб. в месяц. Эта величина на 4\% превышает МРОТ, установленный на 2015 год (5965 рублей).Заявлено об увеличении МРОТ до 7500 руб. с 1 июля 2016 года, тем не менее, по-прежнему отстающего от уровня прожиточного минимума. Планируется, что МРОТ и прожиточный минимум сравняются к 2020 году, но повышение прожиточного минимума не гарантирует моментального и соразмерного повышения МРОТ.

Согласно исследованиям Института социологии РАН, среди работающих граждан в России в 2014 году более 60\% можно отнести к бедным, причем кроме бедняков с детьми есть и хроническая бедность - это около $80 \%$ тех, чья бедность длится более трех лет [8]. Статистика численности населения с денежными доходами ниже прожиточного минимума подтверждает столь негативную динамику (Таблица 3)[3].

Таблийа 3

Численность населения с денежными доходами ниже прожиточного минимума

\begin{tabular}{|c|c|c|}
\hline \multirow{2}{*}{ Годы } & Численность населения с денежными доходами ниже прожиточного минимума \\
\cline { 2 - 3 } & млн. чел. & в \% от общей численности населения \\
\hline 2005 & 25,4 & 17,8 \\
\hline 2006 & 21,6 & 15,2 \\
\hline 2007 & 18,8 & 13,3 \\
\hline 2008 & 19,0 & 13,4 \\
\hline 2009 & 18,4 & 13,0 \\
\hline 2010 & 17,7 & 12,5 \\
\hline 2011 & 17,9 & 12,7 \\
\hline 2012 & 15,4 & 10,7 \\
\hline 2013 & 15,5 & 10,8 \\
\hline 2014 & 16,1 & 11,2 \\
\hline 2015 & 20,1 & 14,0 \\
\hline Процент & Численности населения с денежными доходами \\
\hline
\end{tabular}

прожиточного минимума с 2006 по 2012 года снижается, с 2013 года наблюдается рост,который в 2014 году составил 14\% (20,1 млн. чел.) от общей численности населения, свидетельствующий о том, что только за 2015 год численность населения с денежными доходами ниже прожиточного минимумаувеличилась на 4 млн. чел. 
Серьезное внимание уделяется росту задолженности по оплате труда со стороны работодателей. В целях снижения задолженности необходимы превентивные тенденции государственного инспектирования в социальнотрудовой сфере[4], контроль со стороны профессиональных союзов, представляющих интересы наемных работников [5], налогово-бюджетное регулирование $[6,7]$. Особенно высокая задолженность в сельском хозяйстве, учитывая фактор сезонности [7].

Таким образом, в последнее десятилетие в России наблюдается увеличение прожиточного минимума, определяемого в целом по России, является основой для установления минимального размера оплаты труда и основой формирования федерального бюджета.Тревожная тенденция увеличения удельного веса населения с денежными доходами ниже прожиточного минимума до 20,1 млн. чел. в 2015 году требует использования инструментов государственного регулирования и поддержки. 


\section{Литература:}

1. Бочарова И. Экономические интересы в теориях рационального поведения наемных работников// Вестник Института экономики Российской академии наук. 2007. № 4. С. 93-105.

2. Жеребин В. М., РомановА. Н. Уровеньжизни населения. М.: ЮНИТИДАНА, 2011. 189 c.

3. Официальный портал федеральной службы государственной статистики. URL: http://www.gks.ru.

4. Бочарова И.Ю. Превентивные тенденции государственного инспектирования в социально-трудовой сфере. // Региональная экономика: теория и практика. 2008. № 33. С. 2-5.

5. Бочарова И.Ю. Реформирование института представительства интересов наемных работников. //Труд и социальные отношения. 2005. № 1. С. 29.

6. Рыманов А.Ю. Налогообложение и поддержка товаропроизводителей. // Экономист. 2011. № 9. С. 90-92.

7. Рыманов А.Ю. О налогово-бюджетном регулировании сельского хозяйства. // Экономика сельскохозяйственных и перерабатывающих предприятий. 2004. № 4. С.40-42.

8. Научный электронный журнал «Вестник института социологии».URL:http://www.vestnik.isras.ru. 